\title{
PENCAIRAN TUNGGAKAN PAJAK YANG DIDETERMINASI OLEH PENCAIRAN SURAT TEGURAN DAN PENCAIRAN ATAS SANKSI ADMINISTRASI PAJAK
}

(Studi Pada Kantor Pelayanan Pajak Pratama Bandung Majalaya Tahun 2017-2020)

\author{
Neng Ratna Novita Sari, Cepi Saepuloh \\ Program Studi Akuntansi, STIE Stembi Bandung \\ nengratna18@student.stembi.ac.id, cepisaepuloh@stembi.ac.id
}

\begin{abstract}
ABSTRAK
Kajian ini bertujuan untuk mengetahui pencairan tunggakan pajak yang ditentukan oleh pencairan surat teguran dan pencairan atas sanksi administrasi pajak di Kantor Pelayanan Pajak Pratama Bandung Majalaya tahun 2017-2020. Masalahnya adalah meningkatnya pencairan surat teguran dan pencairan atas sanksi administrasi pajak tetapi pencairan tunggakan pajak menurun. Metode penelitian yang digunakan adalah metode analisis deskriptif dan verifikatif. Teknik sampling dalam penelitian ini menggunakan pengambilan sampel jenuh sehingga sampel penelitian yang diperoleh sebanyak 16 periode pada Tahun 2017-2020. Teknik analisis data yang digunakan adalah analisis regresi linier berganda dan dibantu oleh program aplikasi SPSS versi 26. Hasil penelitian menunjukkan bahwa pencairan surat teguran tidak mempengaruhi pencairan tunggakan pajak dengan hubungan positif dan pencairan denda administrasi pajak mempengaruhi pencairan tunggakan pajak dengan hubungan positif. Secara umum, masih ada wajib pajak yang tidak segera melunasi utang pajaknya, sehingga perlu diberikan sanksi yang lebih berat bagi wajib pajak untuk segera melunasi utangnya.
\end{abstract}

Kata Kunci: Pencairan Surat Teguran, Pencairan atas Sanksi Administrasi dan Pencairan Tunggakan Pajak

\section{ABSTRACT}

This study aims to determine the disbursement of tax arrears that are determined by the disbursement of reprimand letter and disbursement of tax administration penalties in the Tax Office Pratama Bandung Majalaya in Year 2017-2020. The problem is the increasing of disbursement of reprimand letter and disbursement of tax administration penalties but the disbursement of tax arrears decreased. The research method used is descriptive analysis method and verifikatif. Sampling technique in this study using saturated sampling so that the research samples obtained as much as 16 periods in Year 20172020. Data analysis technique used is multiple linear regression analysis and assisted by SPSS application program version 26.

The results showed that the disbursement of the letter of reprimand did not affect the disbursement of tax arrears with a positive relationship and the disbursement of tax administration penalties affected the disbursement of tax arrears with a positive relationship. In general, there are still taxpayers who do not immediately pay off their tax debts, so it is necessary to be given tougher sanctions for taxpayers to immediately pay off their debts.

Keywords: Disbursement Reprimand Letter, Disbursement Tax Administration Penalties and The Disbursement Of Tax Arrears 


\section{PENDAHULUAN}

\section{Latar Belakang}

Tunggakan Pajak adalah pajak yang masih harus dibayar termasuk sanksi administrasi berupa bunga, denda atau kenaikan yang tercantum dalam Surat Ketetapan Pajak atau surat sejenisnya berdasarkan ketentuan peraturan perundang-undangan perpajakan (Panca Kurniawan dan Bagus Pamungkas, 2016). Pencairan tunggakan pajak adalah seluruh pelunasan utang pajak yang dilakukan oleh Wajib Pajak, yang dibayarkan melalui SSP, maupun melalui pengurangan utang pajak karena adanya pengurangan akibat SK Pembetulan maupun SK Keberatan, Putusan Banding dan peninjauan kembali (Siti Kurnia Rahayu, 2017:297). Dengan dilakukan penagihan pajak secara pasif dan aktif diharapkan pencairan tunggakan pajak yang disebabkan karena Wajib Pajak tidak mematuhi aspek material peraturan perpajakan, dapat direalisasikan (Siti Kurnia Rahayu, 2017:297). Penerbitan surat teguran dilakukan apabila dalam waktu yang telah ditentukan wajib pajak belum melakukan pembayaran utang pajak setelah dilakukannya penagihan pasif (Siti Kurnia Rahayu, 2017:296).

Pengenaan sansksi pajak perlu dilakukan kepada wajib pajak yang menyepelekan ketentuan perpajakan supaya wajib pajak tidak mengulanginya (Rizki dkk, 2016). Sanksi administrasi merupakan pembayaran kerugian kepada negara, khususnya yang berupa bunga dan kenaikan (Mardiasmo, 2013:59). Pembayaran tunggakan pajak yang terjadi dipengaruhi oleh perubahan jumlah sanksi administrasi, dengan demikian semakin banyak jumlah sanksi administrasi maka akan semakin banyak pembayaran tunggakan pajak (Sulhan dkk, 2015). Sanksi administrasi sehubungan dengan surat ketetapan pajak dan surat tagihan pajak berdasarkan UU No. 28 Tahun 2007 tentang Ketentuan Umum dan Tata Cara Perpajakan, sanksi administrasi berkaitan dengan denda, bunga dan kenaikan (Siti Resmi, 2016:61).

Berdasarkan data dari seksi penagihan pada Kantor Pelayanan Pajak Pratama Bandung Majalaya yang telah diperoleh, tahun 2018 terdapat kenaikan pencairan surat teguran yang tidak diikuti dengan peningkatan pencairan tunggakan pajak dimana adanya kenaikan pencairan surat teguran akan tetapi pada waktu yang sama pencairan tunggakan pajak menurun, begitu juga untuk pencairan atas sanksi administrasi pajak pada tahun 2017 dimana terdapat peningkatan pencairan atas sanksi administrasi pajak akan tetapi pencairan tunggakan pajak menurun. Dari latar belakang yang telah dipaparkan tersebut, maka penelitian ini akan di beri judul Pencairan Tunggakan Pajak yang Dideterminasi oleh Pencairan Surat Teguran dan Pencairan atas Sanksi Administrasi Pajak.

Rumusan Masalah

Adapun rumusan masalah sebagai berikut:

1. Seberapa besar pengaruh pencairan surat teguran terhadap pencairan tunggakan pajak.

2. Seberapa besar pengaruh pencairan atas sanksi administrasi pajak terhadap pencairan tunggakan pajak.

Tujuan dan Manfaat Penelitian

Tujuan dari penelitian ini adalah:

1. Untuk mengetahui besar pengaruh pencairan surat teguran terhadap pencairan tunggakan pajak.

2. Untuk mengetahui besar pengaruh pencairan atas sanksi administrasi pajak terhadap pencairan tunggakan pajak.

Manfaat dari penelitian ini adalah:

Dari penelitian ini dapat dijadikan bahan perbandingan dari penelitian yang telah ada bagi peneliti lain dan juga memberikan pengalaman belajar yang dapat mengembangkan pengetahuan terutama dalam bidang yang diteliti.

Kajian Pustaka

Surat Teguran

Menurut Aristanti Widyaningsih (2013:308) Surat Teguran adalah:

"Surat Teguran atau dapat juga disebut Surat Peringatan atau surat lain yang sejenis adalah surat yang diterbitkan oleh pejabat untuk menegur atau memperingatkan kepada Wajib Pajak untuk melunasi utang pajaknya". 
Dengan indikator realisasi pencairan surat teguran.

\section{Sanksi Administrasi}

Menurut Rochmat Soemitro (2012:85), Sanksi Administrasi adalah:

"Hukuman yang dijatuhkan oleh pejabat administrasi terhadap wajib pajak yang melanggar ketentuan Undang-Undang yang dikualifikasikan lebih ringan daripada tindak pidana, yang selalu sejumlah uang, baik suatu jumlah yang tetap atau suatu perkalian atau persentase dari jumlah pajak yang terutang".

Dengan indikator realisasi pencairan atas sanksi administrasi pajak.

\section{Pencairan Tunggakan Pajak}

Menurut Waluyo (2013:64), Pencairan Tunggakan Pajak adalah:

"Pencairan Tunggakan Pajak merupakan pembayaran yang dilakukan dengan menggunakan Surat Setoran Pajak yang digunakan untuk pelunasan piutang pajak dan diajukannya keberatan atau banding sehingga mengakibatkan berkurangnya jumlah piutang pajak serta jika penanggung pajak sudah meninggal dunia dan berpindah tempat maka piutang pajak tersebut akan dihapuskan karena penanggung pajak sudah tidak ada atau tidak dapat ditemukan lagi”.

Dengan indikator jumlah pencairan tunggakan pajak.

\section{Kerangka Pemikiran}

Pengaruh Pencairan Surat Teguran terhadap Pencairan Tunggakan Pajak

Menurut Siti Kurnia Rahayu (2017:297):

"Dengan dilakukan penagihan pajak secara pasif dan aktif diharapkan pencairan tunggakan pajak yang disebabkan karena wajib pajak tidak mematuhi aspek material peraturan perpajakan, dapat direalisasikan".

Pengaruh Pencairan atas Sanksi Administrasi Pajak terhadap Pencairan Tunggakan Pajak

Penelitian yang dilakukan Sulhan dkk (2105), menyatakan:

"Pembayaran tunggakan pajak yang terjadi dipengaruhi oleh perubahan jumlah sanksi administrasi, dengan demikian semakin banyak jumlah sanksi administrasi maka akan semakin banyak pembayaran tunggakan pajak".

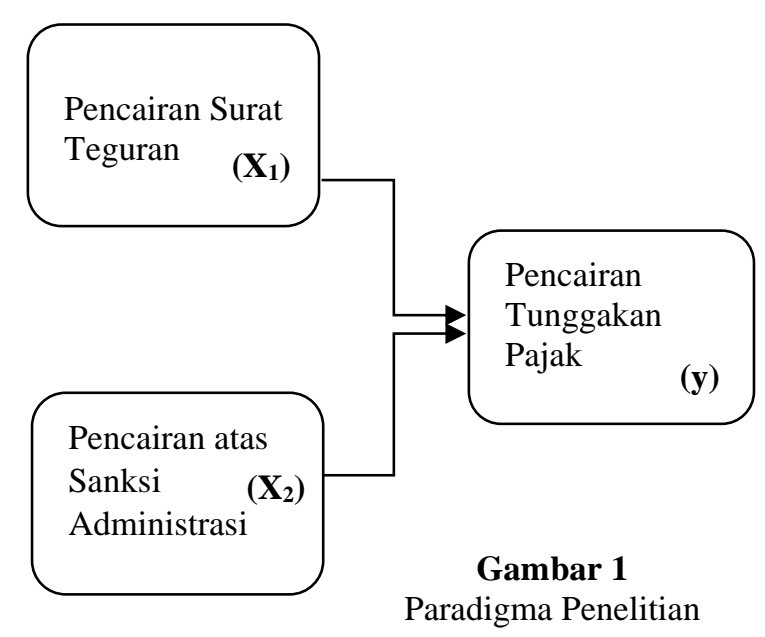

Hipotesis

Peneliti menentukan hipotesis sebagai berikut:

H1 : Pencairan surat teguran berpengaruh terhadap pencairan tunggakan pajak.

$\mathrm{H} 2$ : Pencairan atas sanksi administrasi berpengaruh terhadap pencairan tunggakan pajak.

\section{METODOLOGI PENELITIAN}

Metodologi Penelitian 
Metode deskriptif dan metode verifikatif metode yang akan memberikan bagaimana gambaran atau deskripsi dan apakah penelitian ini dapat membuktikan teori yang telah dijelaskan sebelumnya mengenai keterkaitan dari variabel yang diteliti. Adapun pendekatan kuantitatif untuk mengukur bagaimana pencairan surat teguran dan pencairan atas sanksi administrasi pajak berpengaruh terhadap pencairan tunggakan pajak berdasarkan pengolahan data.

Objek Penelitian

Objek penelitian dalam penelitian ini adalah pencairan surat teguran, pencairan atas sanksi administrasi dan pencairan tunggakan pajak pada Kantor Pelayanan Pajak Pratama Bandung Majalaya

Unit Analisis

Unit analisis dalam penelitian ini adalah Kantor Pelayanan Pajak Pratama Bandung Majalaya pada tahun 2017-2020

Populasi dan Sampel

Populasi

Populasi sasaran dalam penelitian ini adalah data selama 4 tahun (2017-2020) pada Kantor Pelayanan Pajak Pratama Bandung Majalaya, yaitu data Pencairan Surat Teguran, Pencairan atas Sanksi Administrasi Pajak dan Pencairan Tunggakan Pajak

Sampel

Sampling jenuh merupakan teknik penarikan sampel yang digunakan dalam penelitian ini. Adapun sampel yang digunakan sebanyak 16, dari 4 tahun (2017-2020), yaitu data Pencairan Surat Teguran, Pencairan atas Sanksi Administrasi Pajak dan Pencairan Tunggakan Pajak.

Sumber Data dan Teknik Pengumpulan Data

Sumber Data

Sumber data yang akan digunakan dalam penelitian ini berupa data primer dan sekunder yaitu data yang terkait dengan penelitian ini mulai dari tahun 2017-2020 yang diperoleh dari seksi penagihan Kantor Pelayanan Pajak Pratama Bandung Majalaya.

Teknik Pengumpulan Data

Untuk mengumpulkan data, peneliti menggunakan teknik sebagai berikut:

1. Wawancara

Mengadakan wawancara langsung dengan para pegawai bagian seksi penagihan.

2. Dokumentasi

Mengumpulkan data yang diperlukan yang terdapat pada Kantor Pelayanan Pajak Pratama Majalaya.

3. Penelitian Kepustakaan

Memperoleh data yang bersifat teoritis dengan mempelajari buku-buku, dokumen-dokumen, serta skripsi-skripsi terkait masalah lalu pembahasan yang dibutuhkan pada penelitian ini.

Operasional Variabel

Operasionalisasi variabel yang sudah ditetapkan dalam penelitian ini akan sedikit dijelaskan mengenai apa saja variabel yang diteliti, indikator yang digunakan serta skala ukur dari masing-masing variabel, sebagai berikut:

1. Variabel $X_{1}$ yaitu, Surat Teguran dengan indikator realisasi pencairan surat teguran dan menggunakan skala rasio.

2. Variabel $\mathrm{X}_{2}$ yaitu, Sanksi Administrasi dengan indikator realiasai pencairan atas sanksi administrasi pajak dan menggunakan skala rasio.

3. Variabel Y yaitu, pencairan Tunggakan Pajak dengan indikator jumlah Pencairan Tunggakan Pajak dan menggunakan skala rasio.

Metode Pengujian Data

Uji Asumsi Klasik 
Uji asumsi klasik digunakan untuk mengetahui apakah hasil model regresi baik atau sesuai dengan ketentuan dan pengujiannya terdiri atas uji normalitas, uji heteroskedastisitas, uji multikolinearitas, dan uji autokorelasi.

Rancangan Analisis dan Pengujian Hipotesis Rancangan Analisis

1. Analisis Linear Berganda

Analisis regresi linier berganda pada penelitian ini digunakan untuk memprediksi nilai dari pencairan tunggakan pajak yang dideterminasi oleh pencairan surat teguran dan pencairan atas sanksi administrasi pajak.

2. Analisis Korelasi

Analisis korelasi akan menunjukan kekuatan hubungan antara variabel bebas dengan variabel terikat, dalam penelian ini digunakan untuk mengetahui hubungan pencairan surat teguran dengan pencairan tunggakan pajak dan hubungan pencairan atas sanksi administrasi pajak dengan pencairan tunggakan pajak.

3. Analisis Koefisien Determinasi

Analisis koefisien determinasi akan menunjukan besar pengaruh variabel bebas terhadap variabel terikat, dalam penelian ini digunakan untuk mengetahui besarnya pencairan tunggakan pajak yang dipengaruhi pencairan surat teguran dan besarnya pencairan tunggakan pajak yang dipengaruhi pencairan atas sanksi administrasi pajak terhadap. Menggunakan rumus $\mathrm{Kd}=\mathrm{r}^{2} \mathrm{x} 100 \%$ (Umi Narimawati dkk, 2010:50).

Pengujian Hipotesis

Alpha yang digunakan dalam penelitian ini adalah sebesar $5 \%$ atau 0,05 . Untuk lebih lanjut di bawah ini akan menjelaskan seperti apa hipotesis statistik:

$\mathrm{H}_{0}: \beta 1=0 \quad$ :Pencairan Surat Teguran tidak berpengaruh terhadap Pencarian Tunggakan Pajak

$\mathrm{H}_{1}: \beta 1 \neq 0 \quad$ : Pencairan Surat Teguran berpengaruh terhadap Pencarian Pencairan Tunggakan Pajak.

$\mathrm{H}_{0}: \beta 2=0$ : Pencairan atas Sanksi Administrasi tidak berpengaruh terhadap Pencairan Tunggakan Pajak.

$\mathrm{H}_{1}: \beta 2 \neq 0 \quad$ : Pencairan atas Sanksi Administrasi berpengaruh terhadap Pencairan Tunggakan Pajak.

\section{HASIL DAN PEMBAHASAN}

Analisis Deskriptif

1. Pencairan Surat Teguran pada KPP Pratama Bandung Majalaya tahun 2017-2020

Pencairan surat teguran menunjukan nilai pencairan selama periode penelitian mengalami fluktuatif cenderung naik. Terlihat pada gambar 2 dibawah:

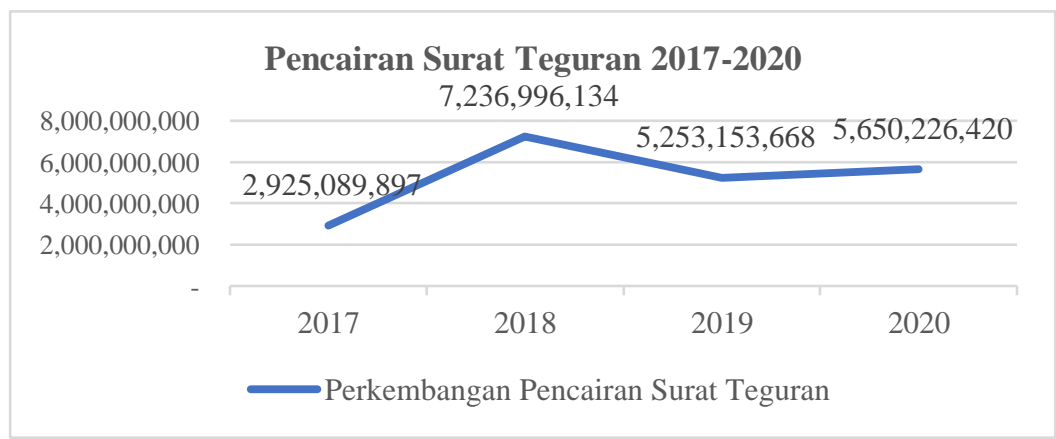

Gambar 2

Grafik Perkembangan Pencairan Surat Teguran

KPP Pratama Bandung Majalaya Periode Tahun 2017 - 2020 
Berdasarkan gambar 2 diatas, dapat dilihat gambaran perkembangan pencairan surat teguran pada Kantor Pelayanan Pajak Pratama Bandung Majalaya tahun 2017-2020 mengalami fluktuatif cenderung naik, terlihat dari pencairan surat teguran pada tahun 2017 dan 2018 mengalami peningkatan dari Rp. 2.925.089.897 pada tahun 2017 naik menjadi Rp. 7.236.996.134 pada tahun 2018. Pada tahun 2019 pencairan surat teguran mengalami penurunan dari tahun sebelumnya menjadi Rp. 5.253.153.668. Namun, pada tahun 2020 kembali mengalami peningkatan menjadi Rp. 5.650.226.420. Peningkatan terjadi karena kesadaran dari penunggak pajak yang menanggapi surat teguran yang diberikan, sehingga segera melunasi utang pajak.

2. Pencairan atas Sanksi Administrasi Pajak pada KPP Pratama Bandung Majalaya tahun 20172020

Pencairan atas sanksi administrasi pajak menunjukan nilai pencairan selama periode penelitian cenderung menurun. Terlihat pada gambar 3 dibawah:

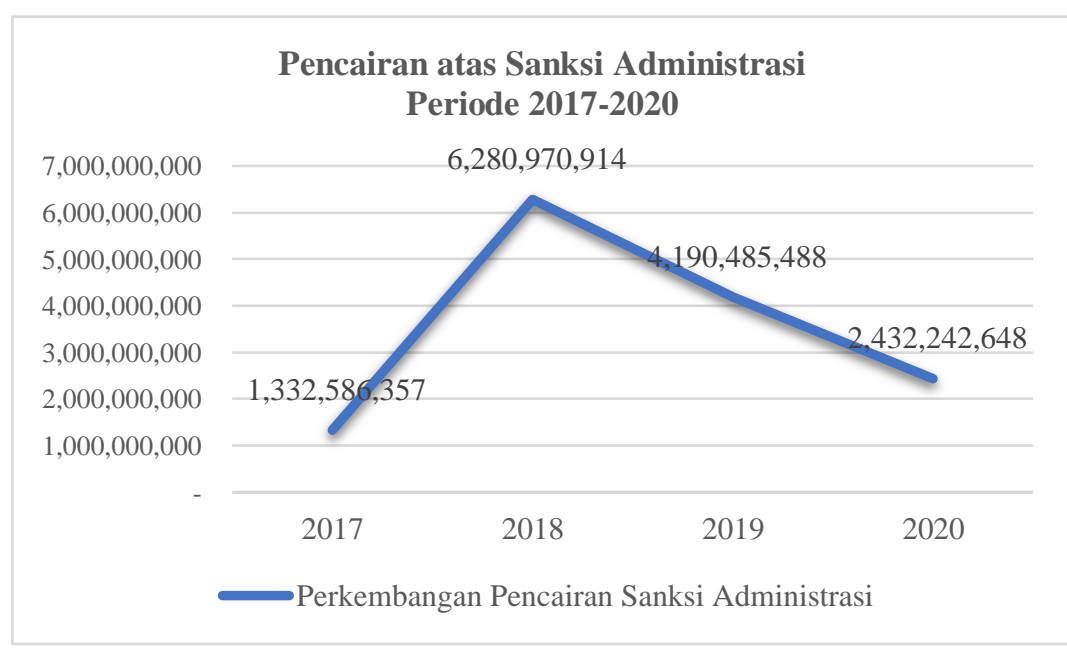

\section{Gambar 3}

Grafik Perkembangan Pencairan atas Sanksi Administrasi

KPP Pratama Bandung Majalaya Periode 2017 - 2020

Berdasarkan gambar 3 diatas, nilai pencairan sanksi administrasi selama periode penelitian cenderung menurun, terlihat dari pencairan sanksi administrasi dari tahun 2017 ke tahun 2018 terjadi peningkatan dari Rp 1.332.586.357 di tahun 2017 menjadi Rp 6.280.970.914 di tahun 2018, tetapi pada dua tahun terakhir terjadi penurunan pencairan sanksi administrasi dari tahun sebelumnya menjadi Rp 4.190.485.488 pada tahun 2019 dan Rp 2.432.242.648 pada tahun 2020 .

3. Pencairan Tunggakan Pajak pada KPP Pratama Bandung Majalaya tahun 2017-2020

Pencairan tunggakan pajak menunjukan nilai pencairan selama periode penelitian mengalami fluktuatif cenderung naik. Terlihat pada gambar 4 dibawah:

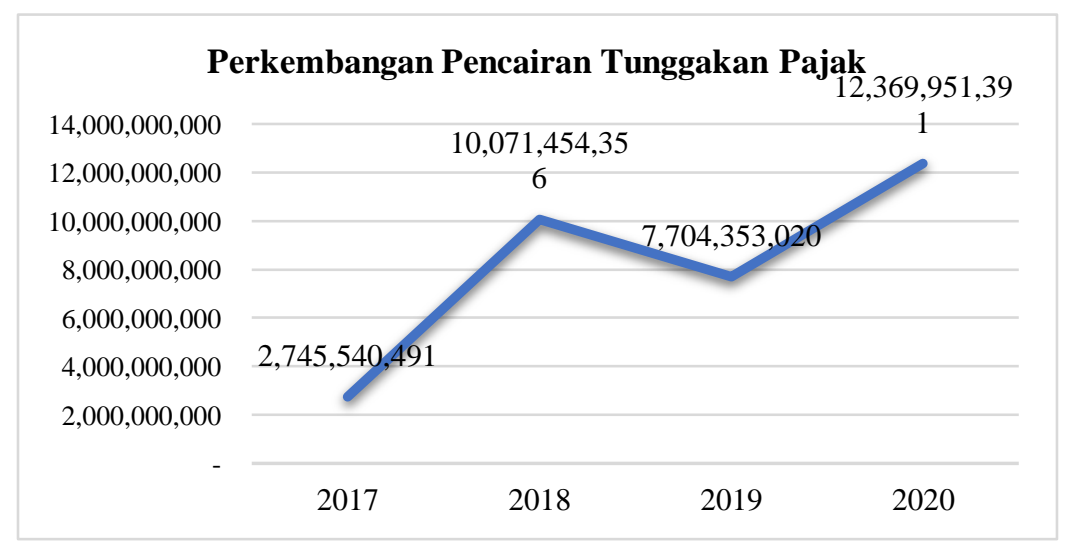

\section{Gambar 4}


Perkembangan Pencairan Tunggakan Pajak

KPP Pratama Bandung Majalaya Periode 2017 - 2020

Berdasarkan gambar 4 di atas menjelaskan, nilai pencairan tunggakan pajak selama periode penelitian berfluktuatif cenderung naik, terlihat dari pencairan tunggakan pajak terendah berada pada tahun 2017 sebesar Rp 2.745.540.491 lalu pencairan tunggakan tertinggi berada di tahun 2020 sebesar Rp 12.369.951.391. Dari tahun 2017 ke tahun 2018 terjadi peningkatan pencairan tunggakan pajak dari Rp 2.745.540.491 di tahun 2017 menjadi Rp 10.071.454.3565 di tahun 2018 dan terjadi penurunan pencairan tunggakan pajak di tahun 2019 sebesar Rp 7.704.353.020, terakhir pada tahun 2020 pencairan mengalami peningkatan dari tahun sebelumnnya menjadi Rp 12.369.951.391.

Analisis Verifikatif

Uji Asumsi Klasik

1. Uji Normalitas

Uji normalitas yang dilakukan memberikan hasil bahwa data dianggap memenuhi asumsi normalitas.

2. Uji Heteroskedasitas

Uji Heteroskedasitas yang dilakukan memberikan hasil bahwa heteroskedastisitas tidak terjadi.

3. Uji Multikolinieritas

Uji multikolinieritas yang dilakukan memberikan hasil bahwa model regresi tidak mengalami multikolinieritas.

4. Uji Autokorelasi

Uji Autokorelasi yang dilakukan memberikan hasil bahwa model regresi tidak mengalami autokorelasi.

Setelah dilakukan uji asumsi klasik dan hasilnya sudah terpenuhi sesuai ketentuan, maka selanjutnya akan dilakukan analisis regresi linier berganda.

Analisis Regresi Linier Berganda

Hasil dari analisis regresi linier berganda:

$$
\mathrm{Y}=554.725 .235+437 \mathrm{X}_{1}+1.041 \mathrm{X}_{2}
$$

Interpretasi persamaan regresi linier berganda adalah:

1. Nilai konstanta sebesar 554.725.235, nilai tersebut merupakan nilai prediksi pencairan tunggakan pajak apabila nilai pencairan surat teguran dan pencairan atas sanksi administrasi bernilai 0 (nol).

2. Nilai pencairan surat teguran sebesar 437, memiliki arti bahwa setiap penambahan 1 pencairan surat teguran, maka diprediksikan pencairan tunggakan pajak akan meningkat sebesar 437.

3. Nilai pencairan atas sanksi administrasi pajak sebesar 1.041, memiliki arti bahwa setiap penambahan 1 pencairan atas sanksi administrasi pajak, maka diprediksikan pencairan tunggakan pajak akan meningkat sebesar 1.041 .

\section{Analisis Koefisien Korelasi}

1. Koefisien korelasi pencairan surat teguran dengan pencairan tunggakan pajak

Dari hasil pengujian mengenai hubungan pencairan tunggakan pajak dengan pencairan surat teguran mempunyai hubungan yang rendah, hasil perhitungan yang positif menunjukkan bahwa terdapat hubungan yang searah sehingga apabila pencairan surat teguran naik maka pencairan tunggakan pajak akan naik.

2. Koefisien korelasi pencairan atas sanksi administrasi pajak dengan pencairan tunggakan pajak Dari hasil pengujian mengenai hubungan pencairan tunggakan pajak dengan pencairan atas sanksi administrasi pajak mempunyai hubungan yang kuat, hasil perhitungan yang positif menunjukkan bahwa terdapat hubungan yang searah sehingga apabila pencairan atas sanksi administrasi pajak naik maka pencairan tunggakan pajak akan naik.

\section{Analisis Koefisien Determinasi}

Berdasarkan hasil penelitian, besar pengaruh pencairan atas sanksi administrasi terhadap pencairan tunggakan pajak memberikan kontribusi atau pengaruh lebih dominan lalu diikuti dengan besar pengaruh pencairan surat teguran terhadap pencairan tunggakan pajak. 


\section{Pengujian Hipotesis}

Adapun alpha yang digunakan yaitu 0,05 atau $5 \%$.

1. Pengujian hipotesis $X_{1}$ pengaruh pencairan surat teguran terhadap pencairan tunggakan pajak Berdasarkan hasil pengujian hipotesis menunjukkan bahwa nilai $\mathrm{t}_{\text {hitung }}$ untuk variabel pencairan surat teguran terhadap pencairan tunggakan pajak sebesar 1,358 dan nilai p-value (Sig.) sebesar 0,197. Dikarenakan nilai thitung lebih kecil dari nilai $t_{\text {tabel }}(1,358<2,160)$ dan nilai signifikansi $0,197<0,05$, artinya secara parsial pencairan surat teguran tidak berpengaruh terhadap pencairan tunggakan pajak pada Kantor Pelayanan Pajak Pratama Bandung Majalaya periode 2017-2020.

2. Pengujian Hipotesis $X_{2}$ pengaruh pencairan atas sanksi administrasi terhadap pencairan tunggakan pajak

Berdasarkan hasil pengujian hipotesis menunjukkan bahwa nilai thitung untuk variabel pencairan atas sanksi administrasi pajak terhadap pencairan tunggakan pajak sebesar 2,740 dan nilai p-value (Sig.) sebesar 0,017. Dikarenakan nilai $t_{\text {hitung }}$ lebih besar dari nilai $t_{\text {tabel }}(2,740>$ 2,160 ) dan nilai signifikansi $0,017<0,05$, artinya secara parsial pencairan atas sanksi administrasi berpengaruh terhadap pencairan tunggakan pajak pada Kantor Pelayanan Pajak Pratama Bandung Majalaya tahun 2017-2020.

Pembahasan

Pengaruh Pencairan Surat Teguran terhadap Pencairan Tunggakan Pajak

Secara parsial pencairan surat teguran tidak berpengaruh terhadap pencairan tunggakan pajak pada Kantor Pelayanan Pajak Pratama Bandung Majalaya periode 2017-2020, tetapi terdapat hubungan yang tergolong dalam kategori hubungan yang rendah juga bersifat positif artinya, setiap kenaikan jumlah pencairan surat teguran maka hal tersebut akan meningkatkan pencairan tunggakan pajak.

\section{Pengaruh Pencairan atas Sanksi Administrasi terhadap Pencairan Tunggakan Pajak}

Secara parsial pencairan atas sanksi administrasi berpengaruh terhadap pencairan tunggakan pajak pada Kantor Pelayanan Pajak Pratama Bandung Majalaya tahun 2017-2020 dan terdapat hubungan yang tergolong dalam kategori hubungan yang kuat juga bersifat positif artinya setiap kenaikan jumlah pencairan atas sanksi administrasi pajak maka akan meningkatkan pencairan tunggakan pajak.

\section{KESIMPULAN DAN SARAN}

\section{Kesimpulan}

Dapat diambil kesimpulan dari penelitian ini sebagai berikut:

1. Pencairan surat teguran tidak berpengaruh terhadap pencairan tunggakan pajak pada Kantor Pelayanan Pajak Pratama Bandung Majalaya tahun 2017-2020 secara parsial. Tetapi, dengan adanya peningkatan jumlah pencairan surat teguran maka jumlah pencairan tunggakan pajak akan sedikit meningkat walau peningkatan tersebut tergolong rendah. Adapun permasalahan yang terjadi dimana masih terdapat wajib pajak yang belum melunasi tunggakan pajak dikarenakan wajib pajak yang kurang merespon surat teguran yang diberikan.

2. Pencairan atas sanksi administrasi berpengaruh terhadap pencairan tunggakan pajak pada Kantor Pelayanan Pajak Pratama Bandung Majalaya tahun 2017-2020 secara parsial. Dengan adanya peningkatan jumlah pencairan atas sanksi administrasi pajak maka jumlah pencairan tunggakan pajak akan meningkat. Adapun permasalahan yang terjadi dimana masih terdapat wajib pajak yang belum melunasi tunggakan pajak dikarenakan wajib pajak yang telah dikenai sanksi administrasi kurang diikuti dengan pembayaran tunggakan pajak.

Saran

Saran Praktis

a. Untuk menambah jumlah dari pencairan tunggakan pajak pada Kantor Pelayanan Pajak Pratama Bandung Majalaya, perlunya pemberian sanksi yang lebih berat serta sosialisasi mengenai batas waktu penagihan pajak kepada wajib pajak apabila setelah diberikan surat teguran wajib pajak 
masih belum mencairkan pajak yang masih harus dibayar dalam surat teguran selama batas waktu yang telah diberikan.

b. Untuk menambah jumlah dari pencairan tunggakan pajak pada Kantor Pelayanan Pajak Pratama Bandung Majalaya, perlunya penambahan sanksi sebagai hukuman serta himbauan mengenai batas waktu dalam kewajiban perpajakan kepada wajib pajak apabila setelah pengenaan sanksi administrasi wajib pajak masih belum melakukan kewajiban perpajakannya.

Saran Akademis

Bagi peneliti yang akan memulai membuat karya ilmiah atau penelitian, saran yang diberikan oleh peneliti adalah untuk menggunakan sumber acuan terbaru serta menambahkan variabel yang akan diteliti atau mengganti salah satu atau semua variabel bebas namun dapat dijelaskan atau sesuai dengan teori yang ada, supaya memperoleh hasil bagaimana pencairan tunggakan pajak dapat dipengaruhi oleh variabel lain.

\section{DAFTAR PUSTAKA}

Aristanti Widyaningsih. 2013. Hukum Pajak dan Perpajakan. Badung : Alfabeta.

M. Sulhan Syahputra, Kadarisman Hidayat Dan Rizki Yudhi Dewantara. 2015. Pengaruh Surat Teguran Surat Paksa Dan Sanksi Administrasi Terhadap Pembayaran Tunggakan Pajak. Jurnal Administrasi Bisnis - Perpajakan. (Vol. 5 No. 1 April 2015).

Mardiasmo. 2013. Perpajakan Edisi Revisi. Yogyakarta: Andi.

Kurniawan, Panca dan Bagus Pamungkas. 2016. Penagihan Pajak di Indonesia, Edisi Pertama. Malang: Bayumedia Publishing.

Rizki Amalia, Topowijono dan Dwiatmanto. 2016. Pengaruh Pengenaan Sanksi Administrasi dan Kesadaran Wajib Pajak terhadap Tingkat Kepatuhan Wajib Pajak Kendaraan Bermotor. Jurnal Administrasi Bisnis (JAB) Vol.21 No.1.Universitas Brawijaya.

Rochmat Soemitro. 2012. Perpajakan Teori dan Teknis Pemungutan. Bandung: Graha Ilmu

Siti Kurnia Rahayu. 2017. Perpajakan Konsep dan Aspek Formal. Bandung : Rekayasa Sains.

Siti Resmi, 2016. Perjakan Teori dan Kasus Edisi 9-Buku 1. Jakarta: Salemba Empat.

Umi Narimawati, Sri Dewi Anggadini, dan Linna Ismawati. 2010. Penulisan Karya Ilmiah. Bekasi: Ganesis

Waluyo. 2013. Perpajakan Indonesia. Jakarta: Salemba Empat. 